\title{
EARLY SUBNEOLITHIC CERAMIC SEQUENCES IN EASTERN FENNOSCANDIA- A BAYESIAN APPROACH
}

\author{
Petro Pesonen $^{1,2} \cdot$ Markku Oinonen $^{3} \cdot$ Christian Carpelan $^{1} \cdot$ Päivi Onkamo ${ }^{2}$
}

\begin{abstract}
In this contribution, we establish a radiocarbon-based chronology of early ceramic sequences in eastern Fennoscandia utilizing a Bayesian approach. The data consist of 56 individual ${ }^{14} \mathrm{C}$ dates from charred or fermented food remains (charred crust, food residue) and birch bark tar used to seal cracks in vessels. We present the results of the models, discuss the chronological boundaries obtained, and compare the outcome with contemporary archaeological knowledge of the Subneolithic in eastern Fennoscandia. We also look at the role of charred crust $\delta^{13} \mathrm{C}$ values as indicators of reservoir effect present in the dates, perform some preliminary correction procedures for the dates, and discuss their effect on the chronologies.
\end{abstract}

\section{INTRODUCTION}

The chronology of the Subneolithic is still heavily laid on the foundation of artifact typology. In eastern Fennoscandia, as elsewhere, changes in the ornamentation and the technology of the ceramics have been considered as chronological boundaries. Furthermore, the regional variability of the ceramics is often interpreted to reflect cultural or technological boundaries between the regions (cf. Carpelan 1999; Pesonen and Leskinen 2009). Accelerator mass spectrometry (AMS) dating has provided a tool to date individual vessels, rendering absolute chronologies with better resolution possible (e.g. Carpelan 1999, 2002; Pesonen 1999a, 2004). Bayesian modeling, introduced into archaeology in the 1990s, allows integrating archaeological knowledge into natural scientific dates to define joint posteriors for the chronological boundaries.

In archaeology, the Bayesian approach has gained popularity during the recent decade, following the pioneering work carried out in 1990s, particularly in Britain (e.g. Buck et al. 1991; Bayliss 2009; Bronk Ramsey 2009a,b). In Finland, the use of the approach has, until recently, been limited to individual radiocarbon calibrations. One of the authors has pioneered the inclusion of stratigraphical information into model dates in Finland, in a project for the Middle Age museum Aboa Vetus in Turku (Oinonen et al. 2011). Within a broader context, the authors' Argeopop project has proceeded in spatiotemporal modeling of past human occupation in the area relying on ${ }^{14} \mathrm{C}$ data to form a timeline for the study (Onkamo et al., these proceedings). In this work, and tightly related to the Argeopop efforts, we perform a Bayesian analysis of early ceramic phases in eastern Fennoscandia.

\section{BACKGROUND: CHRONOLOGY OF SUBNEOLITHIC CERAMICS IN EASTERN FENNOSCANDIA}

Populations in eastern Fennoscandia developed ceramic manufacturing skills under the influence of ceramic traditions in northwestern Russia, beginning about 5300-5200 cal BC. There does not seem to exist any pottery preforms in the region, which indicates that pottery was introduced here either as a ready-made product or as manufactured here by skilled potters. It is known that there were pottery traditions within hunter-gatherer populations in the Volga-Oka interfluve and along the upper reaches of the Volga River already about 6500-6000 cal BC (e.g. Carpelan 1999; Dolukhanov et al. 2005; Tsetlin 2008). The latter has been seen as a source for the early production of ceramics in eastern Fennoscandia, as well (Carpelan 1999:253). From 5300-5200 cal BC onwards, ceramics have

\footnotetext{
${ }^{1}$ Department of Philosophy, History, Culture and Art Studies, University of Helsinki, Finland. Corresponding author. Email: petro.pesonen@gmail.com.

${ }^{2}$ Department of Biosciences, University of Helsinki, Finland.

${ }^{3}$ Finnish Museum of Natural History, Dating Laboratory, University of Helsinki, Finland.
}

(C) 2012 by the Arizona Board of Regents on behalf of the University of Arizona Proceedings of the 6th International Radiocarbon and Archaeology Symposium, edited by E Boaretto and N R Rebollo Franco RADIOCARBON, Vol 54, Nr 3-4, 2012, p 661-676 
been manufactured almost continuously among the hunter-gatherer societies in the region. It should be stressed that in the northern boreal forest zone, the ceramics were not a part of the "Neolithic package," where the agriculture plays a decisive role. Instead, the ceramics were adopted in Subneolithic societies in wide areas of Asia and eastern Europe (e.g. Jordan and Zvelebil 2009).

The wide distribution of ceramics among hunter-gatherer societies and the easily recognizable stylistic and technological changes in it have increased its potential as a chronological marker in archaeology. In Finland and the rest of eastern Fennoscandia, current Subneolithic chronology is strongly founded on the ceramic typology-almost all the phases are named according to ceramic styles. The postglacial uplift of Earth's crust and the corresponding displacement of the shore level made it possible to date the shorebound settlement sites in relation to each other (Europaeus 1926; Europaeus-Äyräpää 1930; Äyräpää 1956). This way, the ceramic typology was linked to shoreline chronology almost $90 \mathrm{yr}$ ago and the ${ }^{14} \mathrm{C}$ dating eventually gave the absolute timing for the periods (e.g. Siiriäinen 1970). The advent of the AMS technique finally provided a tool to directly date the artifacts, at least in special cases. The charred crust and birch bark tar on the pottery surface are such cases, and this possibility has been used widely in archaeology during the last decades in order to gain more accuracy in the dating of the periods. The current chronology of the Finnish Subneolithic is based on individual AMS datings (Carpelan 1999, 2002; Pesonen 1999a, 2004).

Although the ${ }^{14} \mathrm{C}$ methodologies are reasonably well established, systematic uncertainties may occur. Treating the dates among a typological sequence allows for investigating possible outliers. On the other hand, detailed archaeological a priori knowledge on the typological phases has been formed by the archaeological community during the last 100 yr. Bayesian modeling offers a possibility to include this invaluable information of successive typological phases into the actual computational analysis.

\section{METHODOLOGY}

\section{Charred Crust and Birch Bark Tar AMS Radiocarbon Dates}

The data of this study is composed of 55 AMS and 1 GPC dates performed on charred crust or birch bark tar adhered to the surface of Subneolithic pottery in eastern Fennoscandia. In terms of provenance, the study material comes mainly from Finland (38), with additional dates from Norway (10) and Russia (8) (Figure 1, Table 1). Charred crust is a general name for the charred or fermented food remains crusted on the vessel walls. Several studies show that the material most probably derives from a cooking or fermentation process connected with food preparation. The composition of the food ingredients can in some cases be deduced from the crust. The results have shown a great variability in the eating habits throughout the world (e.g. Arrhenius and Lidén 1989; Fischer and Heinemeier 2003; Hopia et al. 2003; Leskinen 2003; Craig et al. 2007 and references therein).

Birch bark tar is a distillation product, which derives from heating wood from birch trees (usually the outer bark) under reducing conditions. A number of uses have been suggested for this product including hafting stone and bone implements, waterproofing and caulking ceramic and other vessels and-because of the tooth marks often visible in the lumps - as a "chewing gum," hence the often used name "chewing resin" (e.g. Pesonen 1999a; Leskinen 2003; Stern et al. 2006; Vahur et al. 2011). One of its uses in eastern Fennoscandia has been sealing the cracks in ceramic vessels, especially during the Typical Combed Ware period $(\sim 4000-3500 \mathrm{cal} \mathrm{BC})$, though some earlier and later examples of birch bark tar use exist (e.g. Carpelan 2004; Leskinen and Pesonen 2005; Pesonen 1994, 1999a). 


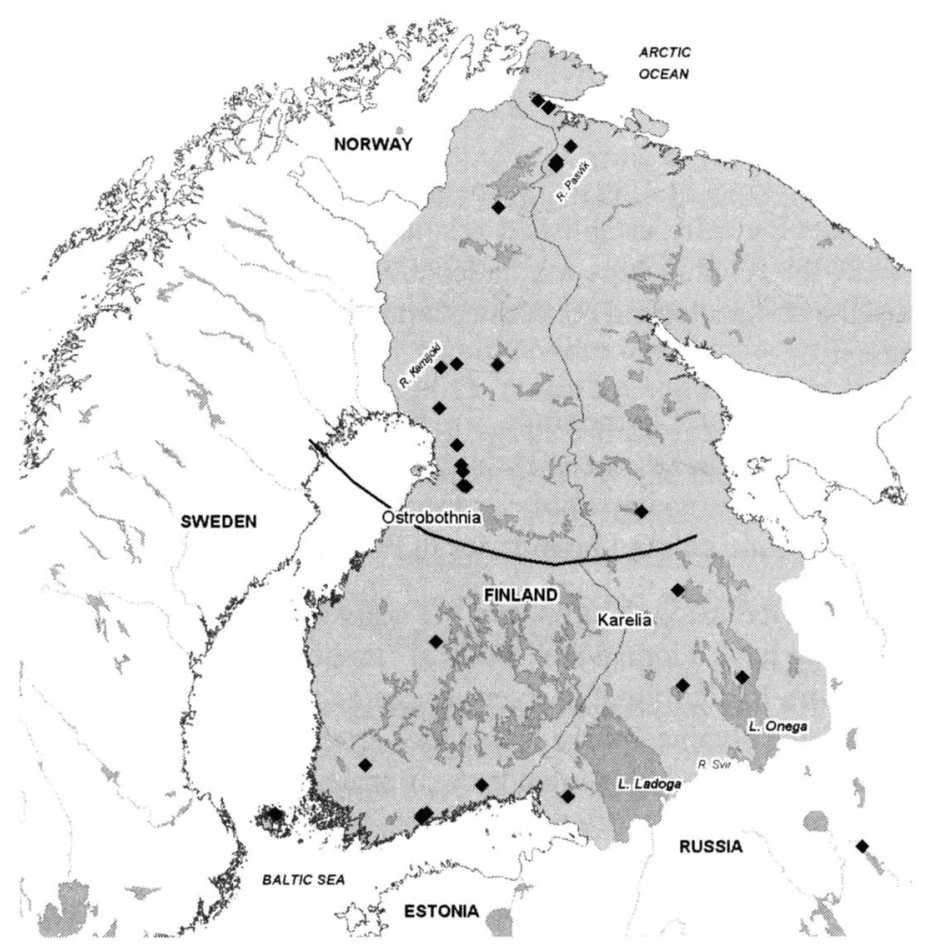

Figure 1 The distribution of Säräisniemi 1, Sperrings 1, and Sperrings 2 ceramic crust and birch bark tar dates in eastern Fennoscandia and the division of the study area into northern and southern areas. The study area comprises Finland without its northwestern arm, a small part of northern Norway east of the Tana River and Fiord, Murmansk Oblast, the Karelian Republic, and part of Leningrad Oblast of Russia. Also, a Sperrings 1 date from Veksa 3 site by Lake Kubana in Vologda Oblast, northwest Russia, has been included in the study.

Table 1 The number of dates on each studied ceramic style from different regions of eastern Fennoscandia.

\begin{tabular}{lllll}
\hline Ceramic type & Norway & Finland & Russia & Total \\
\hline Säräisniemi 1 & 10 & 10 & 2 & 22 \\
Sperrings 1 & & 22 & 6 & 28 \\
Sperrings 2 & & 6 & & 6 \\
Total & $\mathbf{1 0}$ & $\mathbf{3 8}$ & $\mathbf{8}$ & $\mathbf{5 6}$ \\
\hline
\end{tabular}

Most of the dates collected for this study have been published earlier and the use of a few unpublished ones has been consented by the original submitters. The data is included in the database of Finnish archaeological ${ }^{14} \mathrm{C}$ dates, while the ones from the neighboring countries have been collected from the literature and included in the analysis since they were assessed to be representative for this study (e.g. Skandfer 2005, 2009; Hallgren 2008; Piezonka 2008; see Appendix 1 for the full reference list).

The study was restricted to the earliest ceramic styles present in eastern Fennoscandia, i.e. to the archaeological period commonly termed the "Early Combed Ware period." These include Säräisniemi 1, Sperrings 1, and Sperrings 2 traditions. In addition, the early ceramic sequence of eastern 
Fennoscandia includes other contemporary styles as well. These were excluded from this study due to their lack of ${ }^{14} \mathrm{C}$ dates (e.g. Early Asbestos Ware and Jäkärlä Ware; Edgren 1964; Pesonen 1996).

\section{Models}

We have performed the analyses in 2 ways: independently style-by-style (single-phase model) or by assuming certain archaeologically established relationships between the styles (2-phase model). Considering the latter, the relationships are understood as a priori information integrated in the model. This contains the archaeological consensus that has been formed during a century of research into Stone Age pottery.

Due to the limited number of dates in the study, it is not possible to trace the spatiotemporal rate for the spread of ceramic innovations (as in e.g. Dolukhanov et al. 2005). The only attempt in this sense has been to divide the research area into northern and southern sections. The boundaries were drawn between some distinct ceramic cultural boundaries in Finnish and northwest Russian prehistory.

The analyses were conducted using the OxCal v 4.1 software (Bronk Ramsey 2009a) with outlier detection. For outliers, we have adopted the "General" model with the basic settings recommended in Bronk Ramsey (2009b). In addition, the reservoir correction model was experimented for all the data sets. The results for the obtained phase boundaries are discussed as average values provided by the OxCal code. Typically, the posterior calendar year probability distributions for boundaries were reasonably normally distributed to justify this selection. In addition, the mean value is a convenient way to provide point estimates and uncertainties for comparing the posterior calendar year probability distributions. However, we have also given the $1 \sigma$ and $2 \sigma$ highest posterior density regions in Table 2. An example of the OxCal code is given in Appendix 2.

Table 2 Results of the analyses. The datings from literature in column 2 are from Carpelan (1999:273). The models used are single-phase models (individual, allows overlapping) except for the Sperrings 1 and 2 succession in the southern study area, where a 2-phase model with a transition boundary was used. The first and last values in the given cell are the start boundary and the end boundary, respectively. The boundaries between successive phases are marked with an asterisk $(*)$.

\begin{tabular}{|c|c|c|c|c|c|c|c|}
\hline $\begin{array}{l}\text { Ceramic type, } \\
\text { area }\end{array}$ & $\begin{array}{l}\text { Litera- } \\
\text { ture } \\
\text { (cal BC) }\end{array}$ & $\begin{array}{l}\text { Without } \\
\text { reservoir } \\
\text { correction, } \\
\text { mean value } \\
\text { (cal BC) }\end{array}$ & $\begin{array}{l}\text { Without res- } \\
\text { ervoir cor- } \\
\text { rection, } 68 \% \\
\text { HPD region } \\
\text { (cal BC) }\end{array}$ & $\begin{array}{l}\text { Without res- } \\
\text { ervoir cor- } \\
\text { rection, } 95 \% \\
\text { HPD region } \\
\text { (cal BC) }\end{array}$ & $\begin{array}{l}\text { With reser- } \\
\text { voir cor- } \\
\text { rection, } \\
\text { mean value } \\
\text { (cal BC) }\end{array}$ & $\begin{array}{l}\text { With reser- } \\
\text { voir correc- } \\
\text { tion, } 68 \% \\
\text { HPD region } \\
\text { (cal BC) }\end{array}$ & $\begin{array}{l}\text { With reser- } \\
\text { voir correc- } \\
\text { tion, } 95 \% \\
\text { HPD region } \\
\text { (cal BC) }\end{array}$ \\
\hline & & & & & & & \\
\hline $\begin{array}{l}\text { Säräisniemi 1, } \\
\text { South }\end{array}$ & NA & & NA & & & NA & \\
\hline $\begin{array}{l}\text { Sperrings } 1 \text {, } \\
\text { North }\end{array}$ & & & & & & & \\
\hline $\begin{array}{l}\text { Sperrings } 1 \text {, } \\
\text { South }\end{array}$ & & & & & & & \\
\hline $\begin{array}{l}\text { Sperrings 2, } \\
\text { North }\end{array}$ & $\begin{array}{l}4500 \\
4000\end{array}$ & NA & $\mathrm{NA}$ & NA & NA & NA & NA \\
\hline $\begin{array}{l}\text { Sperrings } 2 \text {, } \\
\text { South }\end{array}$ & & & & & & & \\
\hline $\begin{array}{l}\text { Sperrings } 1 \rightarrow 2 \text {, } \\
\text { South }\end{array}$ & $\begin{array}{l}5100 \\
4500^{*} \\
4000\end{array}$ & $\begin{array}{l}5150 \pm 65 \\
4375 \pm 35^{*} \\
4210 \pm 85\end{array}$ & $\begin{array}{l}5200-5075 \\
4420-4340^{*} \\
4315-4185\end{array}$ & $\begin{array}{l}5285-5035 \\
4450-4295^{*} \\
4330-4035\end{array}$ & $\begin{array}{l}5145 \pm 65 \\
4400 \pm 30^{*} \\
4175 \pm 95\end{array}$ & $\begin{array}{l}5195-5070 \\
4430-4370^{*} \\
4300-4130\end{array}$ & $\begin{array}{l}5280-5030 \\
4465-4335^{*} \\
4325-3990\end{array}$ \\
\hline
\end{tabular}




\section{Stable Carbon Isotope Ratios and the Reservoir Effect}

It has been known for a while that the ${ }^{14} \mathrm{C}$ contents of marine organisms differ from the contemporary atmospheric ${ }^{14} \mathrm{C}$ content, reflected by organisms in terrestrial environments. The discrepancy between the ${ }^{14} \mathrm{C}$ ages of the animal or human dieting on marine or terrestrial game is called the reservoir effect. The global average of the reservoir effect is close to $400 \mathrm{yr}$ (Reimer et al. 2009).

Concerning the Arctic Sea, a full reservoir effect of $\mathrm{R}_{\text {Arctic }}=370 \pm 77 \mathrm{yr}$ can be adopted based on the average of the existing 10 measured values along with the coastline (http://calib.qub.ac.uk/ marine/). On the other hand, the history of the Baltic Sea has been characterized by mixing of freshwater and saltwater sources (see e.g. Eronen 2005). Therefore, the size of the reservoir effect within the basin varies both geographically and temporally. The estimates vary depending e.g. on the influence of the Atlantic water masses and on the local topography and the bedrock around the basin (e.g. Olsson 1980, 1991, 1996; Lanting and van der Plicht 1998; Hedenström and Possnert 2001). For the full Baltic Sea reservoir effect, we adopt the average of the 8 measured values available: $279 \pm 77 \mathrm{yr}$ (http://calib.qub.ac.uk/marine/). To account for the suspected spatiotemporal variation, we introduce a slightly larger uncertainty: $R_{B a l t i c}=279 \pm 100 \mathrm{yr}$.

Obviously, the charred food remains crusted on the vessel walls may carry the reservoir effect within the ${ }^{14} \mathrm{C}$ samples, in particular, if the food ingredients were of marine origin. Albeit reservoir effects are mostly known from marine samples, they have also been reported due to freshwater (e.g. Fischer and Heinemeier 2003; Fischer et al. 2007; Olsen and Heinemeier 2007; Philippsen et al. 2010; however, cf. Hart and Lovis 2007). However, due to the lack of significant limestone reservoirs in eastern Fennoscandia, we assume the possible freshwater effect to be fairly limited.

To estimate the proportion of the marine carbon intake, we took a closer look at the $\delta^{13} \mathrm{C}$ values included in the ${ }^{14} \mathrm{C}$ dates of the charred crust samples. Here, all the available prehistoric ceramic crust datings from eastern Fennoscandia were taken into account in order to get a more comprehensive picture of the phenomenon. The isotope values in the charred crust material vary from $-19.3 \%$ to $-32.9 \%$ (on average, $\delta^{13} \mathrm{C}_{\text {crust }}=-26.1 \pm 2.3 \%$ ), while in the purely terrestrial birch bark tar the deviation is clearly smaller, the average being $\delta^{13} \mathrm{C}_{\text {birch bark tar }}=-27.8 \pm 1.0 \%$ (Figure 2). The latter corresponds well to the average value of $-27.9 \%$ obtained by Stern et al. (2006). Generally, the average value for terrestrial samples in the food residue is about $-26 \%$ (Fischer and Heinemeier 2003:460-1).

It is reasonable to assume that all the isotopic values under $-26 \%$ represent terrestrial/freshwater origin, while the values above it may be partly of marine origin. The most negative values are likely due to freshwater fish consumption (Fischer and Heinemeier 2003:463; cf. also Craig et al. 2007; Syväranta and Jones 2008). The above interpretation is supported by the geographical distribution of the $\delta^{13} \mathrm{C}$ values: the highest values derive from charred crust samples found along the ancient shorelines of the seas, whereas the inland values tend to be lower (Figure 3 ). Therefore, we carry out reservoir age corrections for all the charred crust samples having $\delta^{13} \mathrm{C}$ values above $-26 \%$.

We defined an Arctic/Baltic limit at $67^{\circ} \mathrm{N}$. The Baltic reservoir age $\left(\mathrm{R}_{\mathrm{Baltic}}\right)$ was used at the southern side of this limit and the Arctic $\left(\mathrm{R}_{\text {Arctic }}\right)$ at the northern. The method of correction was to assume the highest isotope value in the data $(-19.3 \%)$ to represent $100 \%$ marine carbon intake and to correspond to the full reservoir age $\mathrm{R}_{\mathrm{Baltic}}$ or $\mathrm{R}_{\text {Arctic }}$ and the adopted limit of $-26 \%$ to $100 \%$ terrestrial and, therefore, $R=0$. The corrections were obtained according to the $\delta^{13} \mathrm{C}$ values as a linear interpolation between these extremes. The obtained reservoir age corrections were subtracted from the ${ }^{14} \mathrm{C}$ ages to deduce corrected ages for which the model calibrations were then performed. 

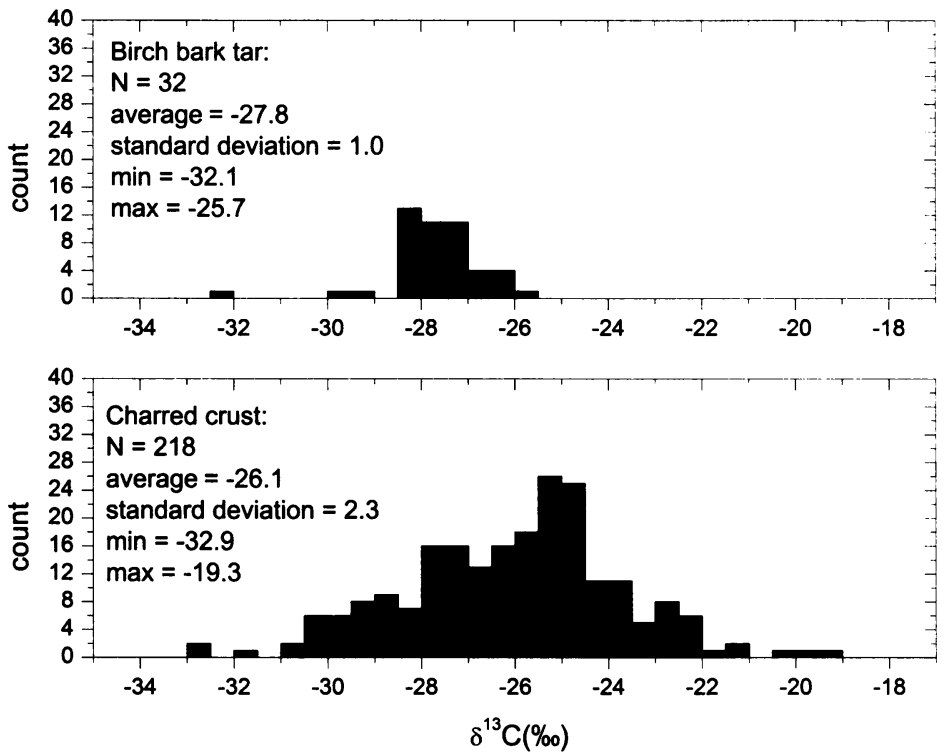

Figure 2 The $\delta^{13} \mathrm{C}$ distributions of the birch bark tar and charred crust samples of the eastern Fennoscandian prehistoric ceramics.

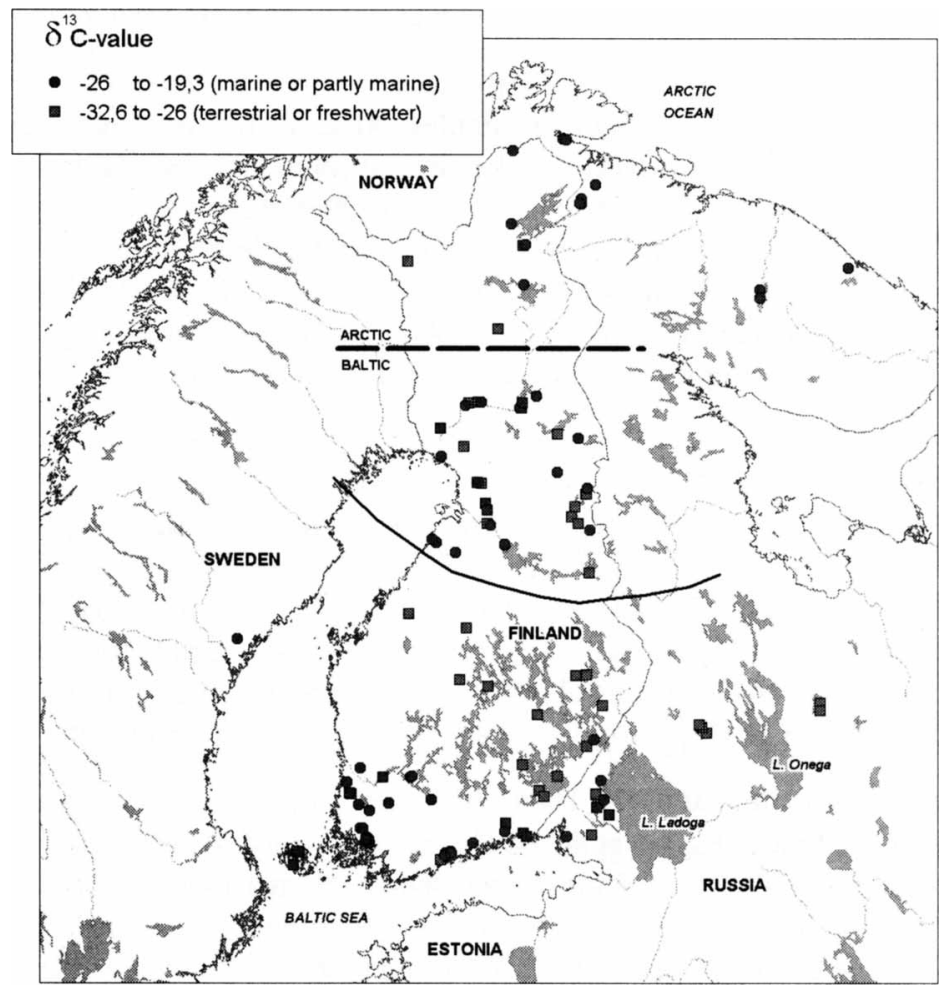

Figure 3 Charred crust $\delta^{13} \mathrm{C}$ values in eastern Fennoscandia. The dashed line marks the border between the Baltic and Arctic reservoir correction, $\sim 67^{\circ} \mathrm{N}$. 
The uncertainties of the corrected ages were due a) the ${ }^{14} \mathrm{C}$ ages, b) the full reservoir ages $\mathrm{R}_{\text {Arctic }}$ ( $\mathrm{R}_{\mathrm{Ba} \text { tic }}$, and $\mathrm{c}$ ) the marine fraction interpolation procedure. We have assumed the analytical uncertainties in $\delta^{13} \mathrm{C}$ values to be negligible. The first 2 contributions being fairly trivial, the uncertainties due to interpolation were obtained as follows. Since the purely terrestrial birch bark tar possesses an average value of $\delta^{13} \mathrm{C}_{\text {birch bark tar }}=-27.8 \pm 1.0 \%$, we assume the uncertainty of the $\delta^{13} \mathrm{C}$ value corresponding to the $100 \%$ terrestrial node of the interpolation to be the same, i.e. $1 \%$. For the $100 \%$ marine node, we have made a survey on the $\delta^{13} \mathrm{C}$ values of muscle of typical marine fauna in the North Atlantic and the Baltic Sea (Hobson et al. 2002; Kiljunen et al. 2006; Sinisalo et al. 2008) and used the standard deviation of all the measured $\delta^{13} \mathrm{C}$ values as a guideline for the node uncertainty. Particularly, we obtained $\sigma_{\text {marine fauna }}=1.6 \%$ and - due to possible uncertainties in the charred crust composition—adopted the absolute $100 \%$ marine node uncertainty to be slightly larger, i.e. $2 \%$. We then sampled the interpolation between these 2 nodes within the adopted uncertainties along with the $\delta^{13} \mathrm{C}$ range in question (from $-19 \%$ to $-26 \%$ ) to obtain the standard deviation for the estimated marine fraction for a given $\delta^{13} \mathrm{C}$ value. This analysis resulted in a linear relation for a maximal $\delta^{13} \mathrm{C}$ dependent uncertainty due to interpolation procedure, and it was used to calculate the marine fraction uncertainty for each sample. Eventually, for the corrected ages, the 3 sources of uncertainty were combined by the law of error propagation. The original and corrected values for each sample are presented in Appendix 1.

\section{RESULTS AND DISCUSSION}

The results according to the ceramic style are given in Table 2. We discuss the results of the analyses style by style.

\section{Säräisniemi 1 Ceramics}

According to the archaeological consensus, the earliest ceramics in eastern Fennoscandia, Säräisniemi 1 and Sperrings 1, were derived from the region south of Lake Onega and the Svir River. From this region, Säräisniemi 1 ware would have spread to the north and Sperrings 1 ware to the west (Carpelan 1999; Gusentsova 2003; Piezonka 2008). While both styles are generally regarded as bearers of the Combed ware tradition, they differ typologically and geographically. The first appearance of ceramics in the northern research area represents Säräisniemi 1 ware. It stands alone without any obvious antecessors or successors. There are altogether $22{ }^{14} \mathrm{C}$ dates available for the style, all but one of charred crust (Figure 4). Two dates were combined to one in the analysis, with a singlephase model employed.

The uncorrected results for the beginning and the end of the era are $5365 \pm 145$ and $4560 \pm 85 \mathrm{cal}$ $\mathrm{BC}$, respectively. The model considers eventually 1 date (Tua-3028) as an outlier with $58 \%$ posterior probability. From all the dates analyzed within this paper, this is the largest posterior outlier probability obtained. Based on this, we consider the correspondence between the ${ }^{14} \mathrm{C}$ data and the cultural phases fairly satisfactory. The initial uncorrected model suggests an early date for the beginning of ceramic production in northern Fennoscandia, $5365 \pm 145 \mathrm{cal} \mathrm{BC}$, with earliest examples deriving from the Varangian coast in the Arctic Ocean and along the Pasvik River on the RussianNorwegian border as well as in the Kalmozero 11 site in Russian Karelia. The earliest Finnish date is from the Pyhänniska site in Utajärvi, north Ostrobothnia, $\sim 300 \mathrm{yr}$ younger than the earliest dates in Norway.

The surprisingly early dates for the Norwegian Säräisniemi 1 ceramics have not really been questioned in Norwegian research, though the possibility of the reservoir effect has been noted (Skandfer 2003, 2005, 2009). These dates were accompanied with high $\delta^{13} \mathrm{C}$ values, thus indicating a need for 


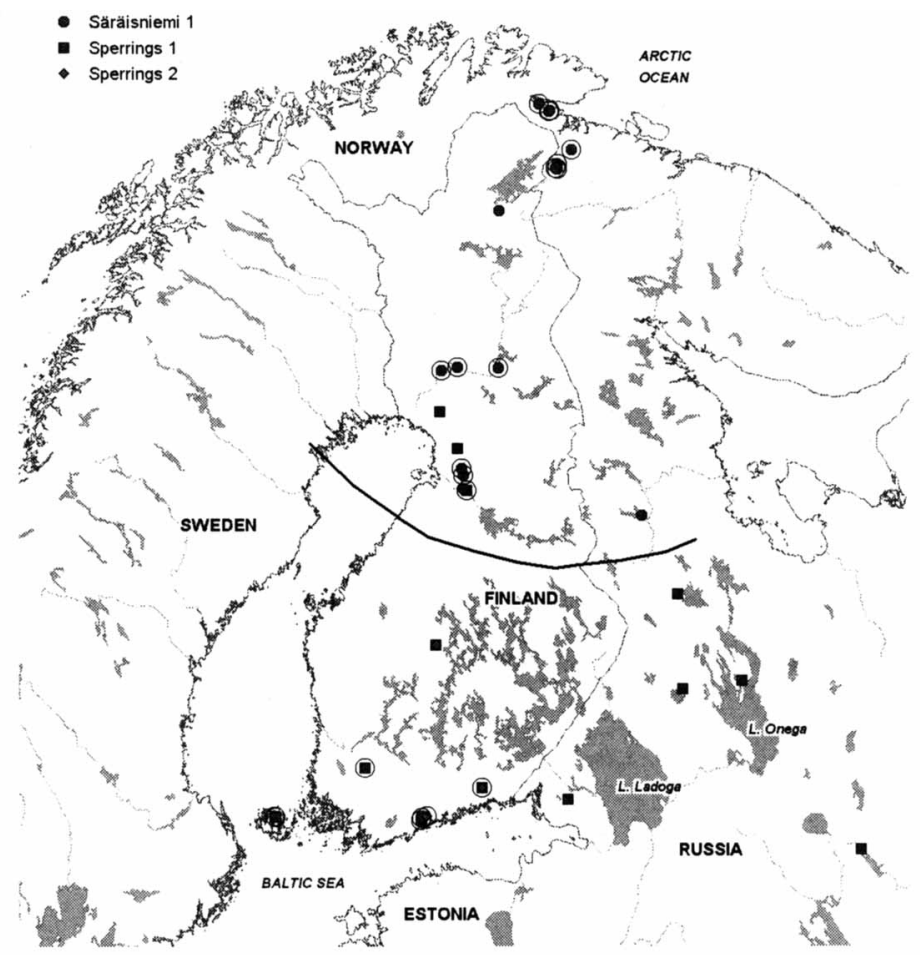

Figure 4 The distribution of Säräisniemi 1, Sperrings 1, and Sperrings 2 samples in the data. A circled symbol denotes that reservoir correction has been performed with the sample in question.

reservoir age correction. In Säräisniemi 1 ceramics, $\delta^{13} \mathrm{C}$ values vary between $-20.3 \%$ and $-30.3 \%$. All the values in the Norwegian coastal area are over $-26 \%$, a value considered as a "marine limit." This holds also for the values along the Kemijoki River in the southern Lapland. Clearly terrestrial/ freshwater values are in the inner Lapland, as expected. Altogether, out of 21 usable dates on the Säräisniemi 1 data set, a significant number of dates $(13$, i.e. $62 \%)$ has a $\delta^{13} \mathrm{C}$ value above $-26 \%$, thus indicating a need for correction.

The reservoir correction makes the boundaries of the Säräisniemi 1 ceramics younger, the beginning and the end of the era being $5190 \pm 100$ and $4455 \pm 110$ cal BC, respectively. The outlier probability for Tua-3028 is decreased to $15 \%$. Therefore, the reservoir age correction makes the data set more consistent, producing smaller outlier probability for Tua-3028 and uncertainty for the beginning of the phase. High $\delta^{13} \mathrm{C}$ values, smaller outlier probability, and reduced uncertainty all support the hypothesis that Norwegian coastal crust dates should be considered as affected by old carbon, probably because of the marine food ingredients in the charred crust (e.g. seal, sea fish, blubber). Due to the lack of more detailed analyses on the compounds in the crust, the reservoir correction must be held as a tentative one, for the time being.

\section{Sperrings 1 and 2 Ceramics}

Another line of stylistic development is seen in Sperrings ceramics, which is a southern variant of the Early Combed Ware, its distribution area overlapping with Säräisniemi 1 ceramics in Russian Karelia, Finnish North Karelia, and North Ostrobothnia (Torvinen 2000; German 2009). There is an older and younger variant within the Sperrings style, called here subsequently Sperrings 1 and Sper- 
rings 2. In our northern research area, Sperrings 1 seems to stand alone, without antecessors or successors in the dating scheme. This is only a partial truth, since Sperrings 2 distribution covers the same area in southern Lapland as Sperrings 1 does (Pesonen 1999b), but so far Sperrings $2{ }^{14} \mathrm{C}$ dates are lacking from the area. In the southern research area, the situation is better. There are altogether 28 Sperrings 1 dates ( 6 from the northern area) and 6 Sperrings 2 dates (Figure 4). The northern dates were treated separately in order to find out whether there was a delay in the arrival of the style to the north (single-phase model). In the southern area, a model was created assuming also a succession from Sperrings 1 to Sperrings 2 ceramics (2-phase model).

The $\delta^{13} \mathrm{C}$ values in Sperrings wares showed some higher, possibly marine-based values and reservoir correction was performed for the dates accordingly. Since all the Sperrings-style dated samples have been found below $67^{\circ} \mathrm{N}$ latitude, the reservoir correction was made with $R_{\text {Baltic }}$. The correction did not significantly affect the boundary ages.

The northern area yields only 6 Sperrings 1 dates and the results indicate that the style indeed arrived there quite late $(4860 \pm 160 \mathrm{cal} \mathrm{BC})$, while its beginning lies in the more southern areas $\sim 300 \mathrm{yr}$ earlier $(5155 \pm 65 \mathrm{cal} \mathrm{BC})$. The results indicate a gradual spreading of Sperrings 1 ceramics to the more northern areas of eastern Fennoscandia, where its distribution area finally overlapped with the distribution area of Säräisniemi 1 ceramics and a hybrid form is found in the contact area (Torvinen 2000: Figure 2).

When assuming the successive Sperrings phases 1 and 2 without an overlapping possibility (2-phase model), the boundary between the older and younger variant is located at $4400 \pm 30 \mathrm{cal} \mathrm{BC}$. Sperrings 2 lasts only about $200 \mathrm{yr}$ according to the model and ends at $4175 \pm 95 \mathrm{cal} \mathrm{BC}$. In the northern area, where the 2-phase model cannot be constructed, the end of Sperrings 1 is modeled at $4505 \pm$ $160 \mathrm{cal} \mathrm{BC}$, i.e. the same within the experimental uncertainties. The analyses with the individual single-phase model (allowing for overlap) and the successive, 2-phase modeling provide nearly similar results.

Traditionally, the phases Sperrings 1 and 2 are dated in Finnish archaeology at about 5100-4500 and 4500-4000 cal BC, respectively (e.g. Carpelan 1999, 2002; Table 2). According to the model results, the Sperrings 1 and Sperrings 2 phases could have slightly altered periods of 5150-4400 and 4400-4200 cal BC, respectively. There are far too few datings of Sperrings 2 ceramics to make definite statements on the duration of the style, however.

\section{CONCLUSIONS}

The results of our journey into Bayesian modeling of the ${ }^{14} \mathrm{C}$ dates can be summarized under 2 headings: 1) the advantages of the modeling and 2) the implications for the Subneolithic chronology in eastern Fennoscandia.

The principal advantage of the Bayesian approach lies in introducing archaeological knowledge into a mathematical procedure in a statistically approved manner. The boundaries in the form of absolute timings should be quite useful for archaeology, e.g. in studying transformations or innovation spread between different areas. Obviously, the more dates, the more accurate the results will be. Assuming strictly successive non-overlapping phases (2-phase models) tends to bring down the modeling uncertainties compared to individual, overlapping phases (single-phase models). In reality, the ceramic traditions may have had some temporal overlap and, therefore, the individually estimated phase boundaries may be more realistic. Nevertheless, we want to point out that models assuming both individual and successive phases provided reasonably similar results in our work. 
According to the reservoir-corrected model, the Säräisniemi 1 ceramics tradition began in the northern regions of eastern Fennoscandia several hundred years later compared to the original data and the uncorrected model (Figure 5). We suggest that some of the early dates are probably affected by the reservoir effect, which is indicated by high $\delta^{13} \mathrm{C}$ values compared to the typical terrestrial/freshwater material and the more consistent reservoir-age corrected data set.

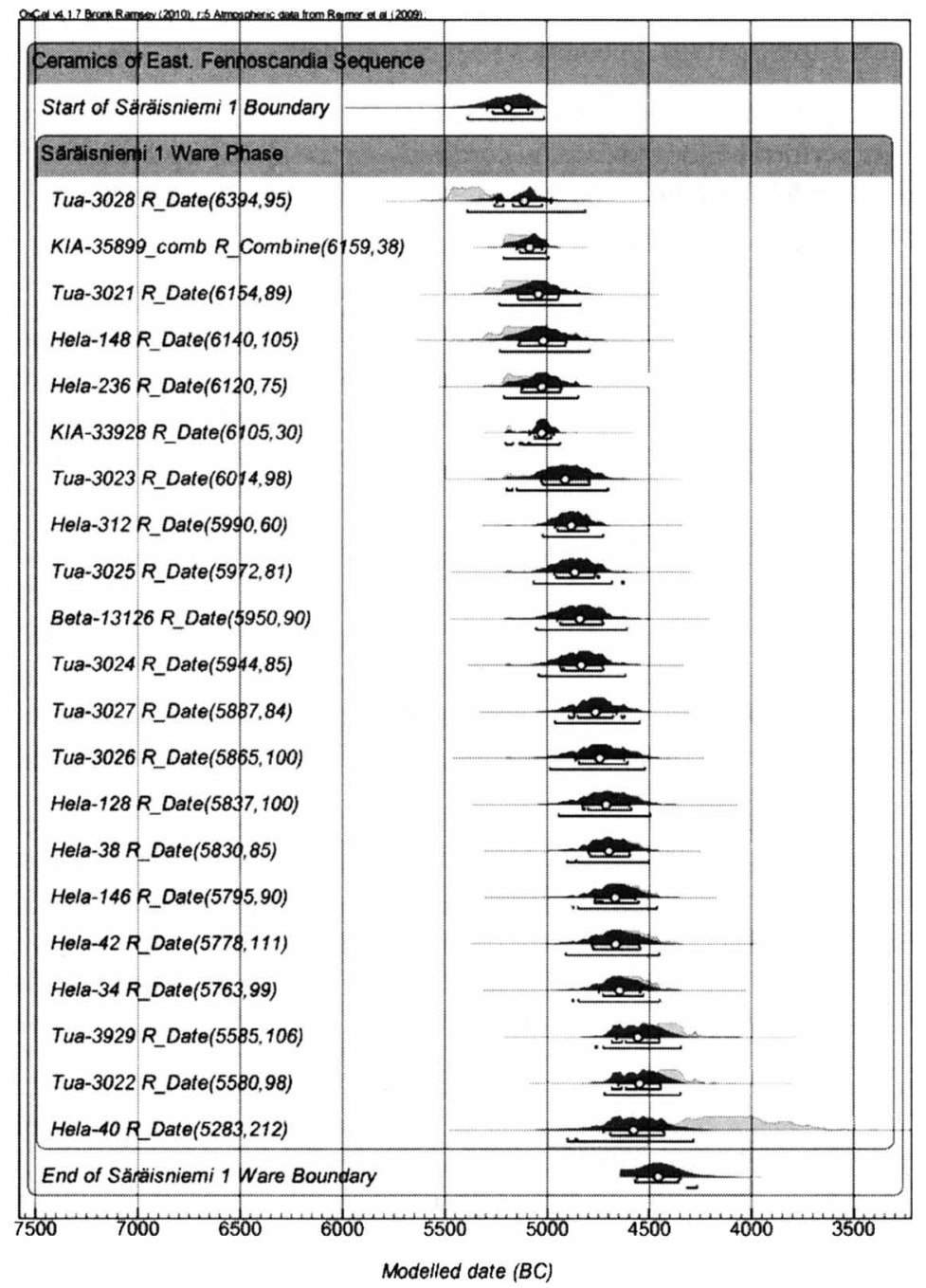

Figure 5 OxCal model for the reservoir-corrected Säräisniemi 1 ceramics serves as an example of the resulting plot. The mean value, its standard deviations, and $95.4 \%$ range of the probability distribution are shown under the individual probability distributions. The OxCal code for this model is given in Appendix 2.

The manufacture of Sperrings 1 ceramics began in the southern area $300 \mathrm{yr}$ earlier compared to the north, i.e. by $\sim 5150 \mathrm{cal} \mathrm{BC}$. The number of Sperrings 1 dates in the northern area is limited thus far, but we suggest that the spread of this tradition in the north was delayed. One reason for this might be the presence of Säräisniemi 1 ceramics tradition bearers in the area. Eventually, the distributions of these ceramic styles overlapped in the Oulu-Kainuu region. The earliest Subneolithic ceramic 
phases of Säräisniemi 1 and Sperrings 1 seem to end nearly at the same period, around $4500-4350$ cal BC, throughout eastern Fennoscandia. The Sperrings 2 style then continues the legacy of Sperrings 1 in the region.

Definitely, the reservoir effect is one of the most serious challenges for future investigations in the Baltic Sea region. Once its magnitude during prehistory can be estimated better, it will be possible to start building schemes of innovation spread in eastern Fennoscandia with better accuracy than before. Charred crust stable isotope ratios of carbon and nitrogen and possibly lipid analyses should yield detailed dietary reconstructions on which more accurate ${ }^{14} \mathrm{C}$ datings could also rely. Another challenge lies in the uneven distribution of AMS dates. More dates are needed, especially from central Russia and the upper reaches of Volga in order to understand the background of the ceramic innovation spread and from Russian Karelia and eastern Baltic, to complement our results. Also, we look forward to the luminescence dating of pottery, which should yield reservoir-age-free results to be compared with the ${ }^{14} \mathrm{C}$ dates.

This paper discusses the Early Subneolithic pottery traditions of eastern Fennoscandia. Middle and Late Subneolithic eastern Fennoscandia experienced major changes in ceramic traditions. Whereas some of the periods are still suffering from lack of data to develop a combined archaeological and natural scientific understanding on them, the future looks fascinating. The forthcoming studies of food residues could bring in massive data sets-with Bayesian modeling tying parts together, while also taking archaeological and environmental understanding into consideration.

\section{ACKNOWLEDGMENTS}

The authors wish to express their gratitude for M A Sirpa Leskinen, who has given her permission to use unpublished ${ }^{14} \mathrm{C}$ dates from Saarijärvi Summassaari Uimaranta site. This study has been partly financed by Oskar Öflund Foundation, E J Sariola Foundation, Emil Aaltonen Foundation, and the Academy of Finland.

\section{REFERENCES}

Arrhenius B, Lidén K. 1989. Fisksoppa eller vegetabilisk gröt? Diskussion kring matresterna från Tybrind Vig. Laborativ Arkeologi 3:6-15.

Äyräpää A. 1956. Den yngre stenålderns kronologi i Finland och Sverige. Finskt Museum 1955:5-47.

Bayliss A. 2009. Rolling out revolution: using radiocarbon dating in archaeology. Radiocarbon 51(1):12347.

Bronk Ramsey C. 2009a. Bayesian analysis of radiocarbon dates. Radiocarbon 51(1):337-60.

Bronk Ramsey C. 2009b. Dealing with outliers and offsets in radiocarbon dating. Radiocarbon 51(3):102345.

Buck C, Kenworthy J, Litton C, Smith A. 1991. Combining archaeological and radiocarbon information: a Bayesian approach to calibration. Antiquity 65(249): 808-21.

Carpelan C. 1979. Om asbestkeramikens historia i Fennoskandien. Finskt Museum 1978:5-25.

Carpelan C. 1999. Käännekohtia Suomen esihistoriassa aikavälillä 5100-1000 eKr. In: Fogelberg P, editor. Pohjan poluilla. Suomalaisten juuret nykytutkimuksen mukaan. Bidrag till kännedom av Finlands natur och folk 153. Helsinki: The Finnish Society of Sciences and Letters. p 249-80.

Carpelan C. 2002. Esihistorian vuosiluvut, ajoitukset ja kronologia. In: Grünthal R, editor. Ennen muinoin miten menneisyyttämme tutkitaan. p 18-27.

Carpelan C. 2004. Environment, archaeology and radiocarbon dates - note from the Inari region, Northern Finnish Lapland. In: Lavento M, editor. Early in the North, Volume 5. Iskos 13. Helsinki: Finnish Antiquarian Society. p 17-45.

Craig OE, Forster M, Andersen SH, Koch E, Crombé P, Milner NJ, Stern B, Bailey GN, Heron CP. 2007. Molecular and isotopic demonstration of the processing of aquatic products in northern European prehistory. Archaeometry 49(1):135-52.

Dolukhanov P, Shukurov A, Gronenborn D, Sokoloff D, Timofeev V, Zaitseva G. 2005. The chronology of Neolithic dispersal in Central and Eastern Europe. Journal of Archaeological Science 32(10): 1441-58.

Edgren T. 1964. Jäkärlä-gruppen. En västfinsk kulturgrupp under yngre stenålder. Suomen Muinaismuistoyhdistyksen Aikakauskirja 64. Helsinki.

Eronen M. 2005. Land uplift: virgin land from the sea. In: 
Eronen M, editor. The Physical Geography of Fennoscandia. Oxford: Oxford University Press. p 17-32.

Europaeus A. 1926. Stenålderskeramik från kustboplatser I Finland. In: Nordman, CA, editor. Nordiska Arkeologmötet i Helsingfors 1925. p. 45-77.

Europaeus-Äyräpää A. 1930. Die relative Chronologie der steinzeitlichen Keramik in Finnland 1-2. Acta Archaeologica 1:165-90, 205-20.

Fischer A, Heinemeier J. 2003. Freshwater reservoir effect in ${ }^{14} \mathrm{C}$ dates of food residue on pottery. Radiocarbon 45(3):449-86.

Fischer A, Olsen J, Richards M, Heinemeier J, Sveinbjörnsdóttir ÁE, Bennike P. 2007. Coast-inland mobility and diet in the Danish Mesolithic and Neolithic: evidence from stable isotope values of humans and dogs. Journal of Archaeological Science 34(12): 2125-50.

German K. 2009. Early hunter-gatherer ceramics in Karelia. Ceramics before Farming. The Dispersal of Pottery among Prehistoric Eurasian Hunter-Gatherers. London: University College London Institute of Archaeology Publications. p 255-80.

Gusentsova TM. 2003. Keramika rannego neolita cevero-vostoka Leningradskoy oblasti. In: Timofeyev VI, Sinitsyna GV, editors. Neolit - eneolit Yuga i neolit Severa Vostochnoy Evropy. Saint Petersburg: IIMK RAN. p 268-76.

Hallgren F. 2008. Identitet I praktik. Lokala, regionala och överrgionala sociala sammanhang inom nordlig trattbägarkultur. Coast to Coast-Book 17. Stockholm.

Hart JP, Lovis WA. 2007. The freshwater reservoir and radiocarbon dates on cooking residues: old apparent ages or a single outlier? Comments on Fischer and Heinemeier (2003). Radiocarbon 49(3): 1403-10.

Hedenström A, Possnert G. 2001. Reservoir ages in Baltic Sea sediment-a case study of an isolation sequence from the Litorina Sea stage. Quaternary Science Reviews 20(18):1779-85.

Hobson KA, Fisk A, Karnovsky N, Holst M, Gagnon J$M$, Fortier M. 2002. A stable isotope $\left(\delta^{13} \mathrm{C}, \delta^{15} \mathrm{~N}\right)$ model for the North Water food web: implications for evaluating trophodynamics and the flow of energy and contaminants. Deep-Sea Research II 49(22-23): 5131-50.

Hopia A, Reunanen M, Pesonen P. 2003. GC-MS analysis of organic residues in the potsherd samples from Vantaa Maarinkunnas [Appendix]. Finskt Museum 1995:44-55.

Jordan P, Zvelebil M, editors. 2009. Ceramics before Farming. The Dispersal of Pottery among Prehistoric Eurasian Hunter-Gatherers. London: University College London Institute of Archaeology Publications.

Jungner H, Sonninen E. 2004. Radiocarbon Dates 6. Report, Dating Laboratory, University of Helsinki.

Kiljunen M, Grey J, Sinisalo T, Harrod C, Immonen H Jones RI. 2006. A revised model for lipid-normalizing $\delta^{13} \mathrm{C}$ values from aquatic organisms, with implications for isotope mixing models. Journal of Applied Eco$\log y$ 43(6):1213-22.

Koivisto S. 1998. Ylikiiminki Vepsänkangas - Sär 1 asuinpaikka Pohjois-Pohjanmaalla: alustavia kaivaustuloksia. In: Ranta H, editor. Kentältä Poimittua 4. Kirjoitelmia arkeologian alalta. Museoviraston arkeologian osaston julkaisuja no7. Helsinki: National Board of Antiquities. p 41-50.

Lanting JN, van der Plicht J. 1998. Reservoir effects and apparent ${ }^{14} \mathrm{C}$-ages. The Journal of Irish Archaeology IX:151-65.

Leskinen S. 2003. On the dating and function of the Comb ceramics from Maarinkunnas. Finskt Museum 1995:5-43.

Leskinen S, Pesonen P. 2005. Kuka pureskeli pihkaa Summasjärven rannalla? Purupihkamälli ja muita metallikautisia löytöjä Saarijärveltä. In: Ranta H, editor. Kentältä poimittua 6. Kirjoitelmia arkeologian alalta. Museoviraston arkeologian osaston julkaisuja noll. Helsinki: National Board of Antiquities. p 48-64.

Leskinen S, Pesonen P. 2008. Vantaan Esihistoria. Vantaan kaupunki.

Luoto J, Terho A. 1988. Kuoppakeraaminen astia Nousiaisten Kirjunpajusta. Faravid 12:7-28.

Oinonen M, Uotila K, Zetterberg P, Hilasvuori E, Nordqvist H. 2011. Context dating of Medieval Turku wiggle matching technique scrutinized at Aboa Vetus. In: Uotila K, editor. Castella Maris Baltici X. Proceedings of the Castella Maris Baltici Symposium (AMAF XVIII Turku 2011).

Olsen J, Heinemeier J. 2007. AMS dating of human bone from the Ostorf cemetery I the light of new information on dietary habits and freshwater reservoir effects. In: Larsson L, Lüth F, Terberger T, editors. Innovation and Continuity - Non-Megalithic Mortuary Practices in the Baltic. New Methods and Research into the Development of Stone Age Society. Bericht der RömischGermanischen Kommission 88. p 339-52.

Olsson IU. 1980. Content of ${ }^{14} \mathrm{C}$ in marine mammals from Northern Europe. Radiocarbon 22(3):662-75.

Olsson IU. 1991. Accuracy and precision in sediment chronology. Hydrobiologia 214(1):25-34.

Olsson IU. 1996. ${ }^{14} \mathrm{C}$ dates and the reservoir effect. In: International Workshop on Isotope-Geochemical Research in the Baltic Region. p 5-23.

Onkamo P, Kammonen J, Pesonen P, Sundell T, Moltchanova E, Oinonen M, Haimila M. 2012. Bayesian spatiotemporal analysis of radiocarbon dates from eastern Fennoscandia. Radiocarbon, these proceedings.

Pesonen P. 1994. Tervanpolton juurilla. Koivutervan käyttö saviastian korjauksessa kivikaudella. Tekniikan Waiheita 1:4-7.

Pesonen P. 1996. Early Asbestos Ware. In: Kirkinen T, editor. Pithouses and Potmakers in Eastern Finland. Reports of the Ancient Lake Saimaa Project. Helsinki Papers in Archaeology no9. Helsinki: University of Helsinki. p 9-39. 
Pesonen P. 1999a. Radiocarbon dating of birch bark pitches in typical comb ware in Finland. In: Huurre M, editor. Dig it All. Papers Dedicated to Ari Siiriäinen. Helsinki: Finnish Antiquarian Society. p 191-7.

Pesonen P. 1999b. Suomen esihistoriallinen keramiikka. InterNet pages for teaching Finnish prehistoric pottery. University of Helsinki. http://www.helsinki.fi/ hum/arla/keram/. Accessed 5 June 2011.

Pesonen P. 2001. Kiteen sarvisuo -lisää varhaisesta asbestikeramiikasta. In: Ranta H, editor. Kentältä Poimittua 5. Kirjoitelmia arkeologian alalta. Museoviraston arkeologian osaston julkaisuja no9. Helsinki: National Board of Antiquities. p 34-56.

Pesonen P. 2004. Neolithic pots and ceramics chronology-AMS-datings of Middle and Late Neolithic ceramics in Finland. In Uino P, editor. Fenno-Ugri et Slavi 2002: Dating and Chronology. Museoviraston arkeologian osaston julkaisuja no 10. Helsinki: National Board of Antiquities. p 87-97.

Pesonen P, Leskinen S. 2009. Pottery of the Stone Age hunter-gatherers in Finland. In: Jordan P, Zvelebil M, editors. Ceramics before Farming. The Dispersal of Pottery among Prehistoric Eurasian Hunter-Gatherers. London: University College London Institute of Archaeology Publications. p 299-318.

Philippsen B, Kjeldsen H, Hartz S, Paulsen H, Clausen I, Heinemeier J. 2010. The hardwater effect in AMS ${ }^{14} \mathrm{C}$ dating of food crusts on pottery. Nuclear Instruments and Methods in Physics Research B 268(7-8):995-8.

Piezonka H. 2008. Neue AMS-Daten zur Frühneolithischen Keramikentwicklung in der Nordosteuropäischen Waldzone. Estonian Journal of Archaeology 12(2):67-113.

Reimer PJ, Baillie MGL, Bard E, Bayliss A, Beck JW, Blackwell PG, Bronk Ramsey C, Buck CE, Burr GS, Edwards RL, Friedrich M, Grootes PM, Guilderson TP, Hajdas I, Heaton TJ, Hogg AG, Hughen KA, Kaiser KF, Kromer B, McCormac FG, Manning SW, Reimer RW, Richards DA, Southon JR, Talamo S, Turney CSM, van der Plicht J, Weyhenmeyer CE. 2009. IntCal09 and Marine09 radiocarbon age calibration curves, 0-50,000 years cal BP. Radiocarbon 51(4): 1111-50.

Schulz E-L. 2004. Ankkapurhan arkeologisen aineiston radiohiiliajoitukset. Ammoin Ankkapurhassa. Kymenlaaksossa kivikaudella. Helsinki. p 46.

Siiriäinen A. 1970. Studies relating to shore displace- ment and Stone Age chronology in Finland. Finskt Museum 1973:5-22.

Sinisalo T, Jones RI, Helle E, Valtonen ET. 2008. Changes in diets of individual Baltic ringed seals (Phoca hispida botnica) during their breeding season inferred from stable isotope analysis of multiple tissues. Marine Mammal Science 24:159-70.

Skandfer M. 2003. Tidlig, nordlig kamkeramikk. Typologi-kronologi-kultur [unpublished $\mathrm{PhD}$ thesis]. University of Tromsø.

Skandfer M. 2005. Early Northern Comb Ware in Finnmark: the concept of Säräisniemi 1 reconsidered. Fennoscandia Archaeologica XXII:3-23.

Skandfer M. 2009. Exploring the role of technological choice in Early Northern Comb Ware. In: Jordan P, Zvelebil M, editors. Ceramics before Farming. The Dispersal of Pottery among Prehistoric Eurasian Hunter-Gatherers. London: University College London Institute of Archaeology Publications. p 347-73.

Stenbäck N. 2003. Människorna vid havet - platser och keramik på ålandsöarna perioden 3500-2000 f.Kr. Stockholm Studies in Archaeology 28.

Stern B, Clelland SJ, Nordby CC, Urem-Kotsou D. 2006. Bulk stable light isotopic ratios in archaeological birch bark tars. Applied Geochemistry 21(10):166873.

Syväranta J, Jones RI. 2008. Changes in feeding niche widths of perch and roach following biomanipulation, revealed by stable isotope analysis. Freshwater Biology 53(3):425-34.

Takala H, Sirviö T. 2003. Telkkälä, Muolaa: a multi-period dwelling site on the Karelian Isthmus. Fennoscandia Archaeologica 20:55-77

Torvinen M. 2000. Säräisniemi 1 Ware. Fennoscandia Archaeologica 17:3-35.

Tsetlin YB. 2008. Neolit tsentra Russkoy ravniny. Ornmentatsiya keramiki $i$ metodika periodizatsii kul'tur (Summary: The center of the Russian plane in the Neolithic Age. Decoration of clay vessels and methods for the periodizatin of cultures). Tula: IA RAN.

Vahur S, Kriiska A, Leito I. 2011. Investigation of the adhesive residue on the flint insert and the adhesive lump found from the Pulli Early Mesolithic site (Estonia) by micro-ATR-FT-IR spectroscopy. Estonian Journal of Archaeology 15(1):3-17. 


\section{APPENDICES}

Appendix 1 The ${ }^{14} \mathrm{C}$ dates used in the study. Explanations: Sär $1=$ Säräisniemi 1; Spr $1=$ Sperrings 1 ; Spr $2=$ Sperrings $2 ;(\#)=$ combined dates; $\left({ }^{*}\right)=$ date was not included in the study due to uncertainties of sample content; $(F)=$ Finland; $(\mathrm{N})=$ Norway; $(\mathrm{R})=$ Russia; $\mathrm{S}=$ southern area; $\mathrm{N}=$ northern area; $\mathrm{CC}=$ charred crust; $\mathrm{BBT}=$ birch bark tar.

\begin{tabular}{|c|c|c|c|c|c|c|c|c|}
\hline Lab code & Site & Area & $\begin{array}{l}\text { Age } \\
\text { (BP) }\end{array}$ & $\begin{array}{l}\delta^{13} \mathrm{C} \\
(\%)\end{array}$ & $\begin{array}{l}\text { Reservoir- } \\
\text { corrected } \\
\text { age (BP) }\end{array}$ & $\begin{array}{l}\text { Mate- } \\
\text { rial }\end{array}$ & $\begin{array}{l}\text { Cera- } \\
\text { mics }\end{array}$ & References \\
\hline Ua-17856 & $\begin{array}{l}\text { Saltvik Östra Jansmyra I } \\
\text { (F) }\end{array}$ & $S$ & $6186 \pm 120$ & -26.8 & & $\mathrm{CC}$ & Spr 1 & $\begin{array}{l}\text { Stenbäck 2003; } \\
\text { Hallgren } 2008\end{array}$ \\
\hline KIA-33927 & Veksa $3(\mathrm{R})$ & $\mathrm{S}$ & $6185 \pm 30$ & -30.3 & & $\mathrm{CC}$ & Spr 1 & Piezonka 2008 \\
\hline Ua-17859 & $\begin{array}{l}\text { Saltvik Vargstensslätten } \\
\text { II (F) }\end{array}$ & $\mathrm{S}$ & $6165 \pm 75$ & -26.4 & & $\mathrm{CC}$ & Spr 1 & $\begin{array}{l}\text { Stenbäck 2003; } \\
\text { Hallgren } 2008\end{array}$ \\
\hline Ua-17854 & $\begin{array}{l}\text { Saltvik Östra Jansmyra I } \\
\text { (F) }\end{array}$ & $\mathrm{S}$ & $6100 \pm 75$ & -25.7 & $6088 \pm 84$ & $\mathrm{CC}$ & Spr 1 & $\begin{array}{l}\text { Stenbäck 2003; } \\
\text { Hallgren } 2008\end{array}$ \\
\hline KIA-36724 & Sulgu 2 (R) & $\mathrm{S}$ & $6085 \pm 30$ & & & $\mathrm{CC}$ & Spr 1 & Piezonka 2008 \\
\hline Ua-17855 & $\begin{array}{l}\text { Saltvik Östra Jansmyra I } \\
\text { (F) }\end{array}$ & $S$ & $6065 \pm 80$ & -24.8 & $6015 \pm 91$ & $\mathrm{CC}$ & Spr 1 & $\begin{array}{l}\text { Stenbäck 2003; } \\
\text { Hallgren } 2008\end{array}$ \\
\hline Hela-395 & Kouvola Ankkapurha (F) & $\mathrm{S}$ & $6060 \pm 60$ & -26.5 & & $\mathrm{CC}$ & Spr 1 & Schulz 2004 \\
\hline KIA-33925 & Sulgu $2(\mathrm{R})$ & $\mathrm{S}$ & $6015 \pm 30$ & & & BBT & Spr 1 & Piezonka 2008 \\
\hline Ua-17857 & $\begin{array}{l}\text { Saltvik Vargstensslätten } \\
\text { II (F) }\end{array}$ & $\mathrm{S}$ & $5990 \pm 90$ & -25.8 & $5982 \pm 97$ & $\mathrm{CC}$ & Spr 1 & $\begin{array}{l}\text { Stenbäck 2003; } \\
\text { Hallgren 2008 }\end{array}$ \\
\hline Ua-17858 & $\begin{array}{l}\text { Saltvik Vargstensslätten } \\
\text { II (F) }\end{array}$ & $\mathrm{S}$ & $5990 \pm 75$ & -25.5 & $5970 \pm 84$ & $\mathrm{CC}$ & Spr 1 & $\begin{array}{l}\text { Stenbäck 2003; } \\
\text { Hallgren } 2008\end{array}$ \\
\hline Hela-442 & Saarijärvi Rusavierto (F) & $\mathrm{S}$ & $5985 \pm 80$ & -27.9 & & $\mathrm{CC}$ & Spr 1 & Leskinen 2002 \\
\hline Hela-149 & Utajärvi Roinila (F) & $\mathrm{N}$ & $5975 \pm 105$ & -25.6 & $5959 \pm 112$ & $\mathrm{CC}$ & Spr 1 & $\begin{array}{l}\text { Jungner and } \\
\text { Sonninen } 2004\end{array}$ \\
\hline Hela-80 & Simo Tainiaro (F) & $\mathrm{N}$ & $5940 \pm 100$ & -27.6 & & $\mathrm{CC}$ & Spr 1 & $\begin{array}{l}\text { Jungner and } \\
\text { Sonninen } 2004\end{array}$ \\
\hline Ua-32194 & Vantaa Palmu (F) & $S$ & $5925 \pm 45$ & -24.8 & $5875 \pm 63$ & $\mathrm{CC}$ & Spr 1 & $\begin{array}{l}\text { Leskinen and } \\
\text { Pesonen } 2008\end{array}$ \\
\hline Hela-79 & Simo Tainiaro $(F)$ & $\mathrm{N}$ & $5920 \pm 100$ & -28.6 & & $\mathrm{CC}$ & Spr 1 & $\begin{array}{l}\text { Jungner and } \\
\text { Sonninen } 2004\end{array}$ \\
\hline Hela-887 & Vantaa Viinikkala $2(\mathrm{~F})$ & $\mathrm{S}$ & $5865 \pm 55$ & -26.0 & $5865 \pm 66$ & $\mathrm{CC}$ & Spr 1 & $\begin{array}{l}\text { Leskinen and } \\
\text { Pesonen } 2008\end{array}$ \\
\hline Hela-554 & Muolaa Telkkälä (R) & $S$ & $5830 \pm 80$ & -27.5 & & $\mathrm{CC}$ & Spr 1 & $\begin{array}{l}\text { Takala and } \\
\text { Sirviö } 2003\end{array}$ \\
\hline Hela-886 & Vantaa Viinikkala $2(\mathrm{~F})$ & $S$ & $5805 \pm 50$ & -25.9 & $5801 \pm 62$ & $\mathrm{CC}$ & Spr 1 & $\begin{array}{l}\text { Leskinen and } \\
\text { Pesonen } 2008\end{array}$ \\
\hline Hela-394 & Kouvola Ankkapurha (F) & $\mathrm{S}$ & $5800 \pm 70$ & -26.1 & & $\mathrm{CC}$ & Spr 1 & Schulz 2004 \\
\hline KIA-33924 & Panozero $1(\mathrm{R})$ & $\mathrm{S}$ & $5795 \pm 35$ & & & BBT & Spr 1 & Piezonka 2008 \\
\hline Hel-2376 & Loimaa Kojonperä (F) & $S$ & $5790 \pm 140$ & -25.0 & $5749 \pm 146$ & $\mathrm{CC}$ & Spr 1 & $\begin{array}{l}\text { Luoto and } \\
\text { Terho } 1988\end{array}$ \\
\hline Hela-96 & Yli-Ii Pahkakoski 1 (F) & $\mathrm{N}$ & $5770 \pm 80$ & -28.4 & & $\mathrm{CC}$ & Spr 1 & $\begin{array}{l}\text { Jungner and } \\
\text { Sonninen } 2004\end{array}$ \\
\hline Hela-99 & Yli-Ii Pahkakoski 1 (F) & $\mathrm{N}$ & $5745 \pm 130$ & -26.2 & & $\mathrm{CC}$ & Spr 1 & $\begin{array}{l}\text { Jungner and } \\
\text { Sonninen } 2004\end{array}$ \\
\hline Hela-445 & Kouvola Ankkapurha (F) & $\mathrm{S}$ & $5650 \pm 80$ & -25.2 & $5617 \pm 90$ & $\mathrm{CC}$ & Spr 1 & Schulz 2004 \\
\hline Hela-98 & Yli-Ii Pahkakoski 1 (F) & $\mathrm{N}$ & $5615 \pm 95$ & -27.9 & & $\mathrm{CC}$ & Spr 1 & $\begin{array}{l}\text { Jungner and } \\
\text { Sonninen } 2004\end{array}$ \\
\hline Hela-443 & Kouvola Ankkapurha (F) & $\mathrm{S}$ & $5595 \pm 90$ & -27.1 & & $\mathrm{CC}$ & Spr 1 & Schulz 2004 \\
\hline Hela-546 & $\begin{array}{l}\text { Saarijärvi Summassaari } \\
\text { Uimaranta }(F)\end{array}$ & $\mathrm{S}$ & $5590 \pm 75$ & -27.4 & & BBT & Spr 1 & Unpublished \\
\hline KIA-35901 & Vozmaricha $26(\mathrm{R})$ & $S$ & $5505 \pm 50$ & & & $\mathrm{CC}$ & Spr 1 & Piezonka 2008 \\
\hline Hela-446 & Kouvola Ankkapurha (F) & $\mathrm{S}$ & $5590 \pm 70$ & -23.9 & $5503 \pm 88$ & $\mathrm{CC}$ & Spr 2 & Schulz 2004 \\
\hline Hela-392 & Kouvola Ankkapurha (F) & $\mathrm{S}$ & $5510 \pm 60$ & -26.6 & & $\mathrm{CC}$ & Spr 2 & Schulz 2004 \\
\hline
\end{tabular}


Appendix 1 The ${ }^{14} \mathrm{C}$ dates used in the study. Explanations: Sär $1=$ Säräisniemi 1; Spr $1=$ Sperrings 1; Spr $2=$ Sperrings $2 ;(\#)=$ combined dates; $(*)=$ date was not included in the study due to uncertainties of sample content; $(\mathrm{F})=$ Finland; $(\mathrm{N})=$ Norway; $(\mathrm{R})=$ Russia; $\mathrm{S}=$ southern area; $\mathrm{N}=$ northern area; $\mathrm{CC}=$ charred crust $\mathrm{BBT}=$ birch bark tar. (Continued)

\begin{tabular}{|c|c|c|c|c|c|c|c|c|}
\hline Lab code & Site & Area & $\begin{array}{l}\text { Age } \\
\text { (BP) }\end{array}$ & $\begin{array}{l}\delta^{13} \mathrm{C} \\
(\% 0)\end{array}$ & $\begin{array}{l}\text { Reservoir- } \\
\text { corrected } \\
\text { age (BP) }\end{array}$ & $\begin{array}{l}\text { Mate- } \\
\text { rial }\end{array}$ & $\begin{array}{l}\text { Cera- } \\
\text { mics }\end{array}$ & References \\
\hline Ua-32193 & Vantaa Storskogen (F) & $\mathrm{S}$ & $5415 \pm 45$ & -25.7 & $5403 \pm 58$ & $\mathrm{CC}$ & Spr 2 & $\begin{array}{l}\text { Leskinen and } \\
\text { Pesonen } 2008\end{array}$ \\
\hline Hela-444 & Kouvola Ankkapurha (F) & S & $5410 \pm 75$ & -26.0 & $5410 \pm 83$ & $\mathrm{CC}$ & Spr 2 & Schulz 2004 \\
\hline Hela-393 & Kouvola Ankkapurha (F) & $\mathrm{S}$ & $5360 \pm 70$ & -23.8 & $5269 \pm 89$ & $\mathrm{CC}$ & Spr 2 & Schulz 2004 \\
\hline Hela-642 & $\begin{array}{l}\text { Saarijärvi Summassaari } \\
\text { Uimaranta (F) }\end{array}$ & $\mathrm{S}$ & $5335 \pm 45$ & -29.4 & & $\mathrm{CC}$ & Spr 2 & unpublished \\
\hline Tua-3028 & Nesseby Nordli (N) & $\mathrm{N}$ & $6570 \pm 60$ & -22.8 & $6394 \pm 95$ & $\mathrm{CC}$ & Sär 1 & $\begin{array}{l}\text { Skandfer 2005, } \\
2009\end{array}$ \\
\hline KIA-35899\# & Kalmozero $11(\mathrm{R})$ & $\mathrm{N}$ & $6340 \pm 70$ & & & $\mathrm{CC}$ & Sär 1 & Piezonka 2008 \\
\hline Tua-3021 & Nesseby Nordli (N) & $\mathrm{N}$ & $6330 \pm 50$ & -22.8 & $6154 \pm 89$ & $\mathrm{CC}$ & Sär 1 & $\begin{array}{l}\text { Skandfer 2005, } \\
2009\end{array}$ \\
\hline Tua-3023 & $\begin{array}{l}\text { Sör-Varanger Noatun In- } \\
\text { nmarken }(\mathrm{N})\end{array}$ & $\mathrm{N}$ & $6185 \pm 65$ & -22.9 & $6014 \pm 98$ & $\mathrm{CC}$ & Sär 1 & $\begin{array}{l}\text { Skandfer 2005, } \\
2009\end{array}$ \\
\hline Hela-148 & Utajärvi Pyhänniska (F) & $\mathrm{N}$ & $6140 \pm 105$ & -27.5 & & $\mathrm{CC}$ & Sär 1 & vinen 2000 \\
\hline Hela-236 & Oulu Vepsänkangas (F) & $\mathrm{N}$ & $6120 \pm 75$ & -26.3 & & $\mathrm{CC}$ & Sär 1 & Torvinen 2000 \\
\hline KIA-35899\# & Kalmozero $11(\mathrm{R})$ & $\mathrm{N}$ & $6080 \pm 45$ & & & $\mathrm{CC}$ & Sär 1 & Piezonka 2008 \\
\hline Tua-3024 & Nesseby Lossoas hus (N) & $\mathrm{N}$ & $6065 \pm 55$ & -23.8 & $5944 \pm 85$ & $\mathrm{CC}$ & Sär 1 & $\begin{array}{l}\text { Skandfer } 2005 \text {, } \\
2009\end{array}$ \\
\hline Tua-3025 & $\begin{array}{l}\text { Sör-Varanger Inganeset } \\
\text { (N) }\end{array}$ & $\mathrm{N}$ & $6065 \pm 55$ & -24.3 & $5972 \pm 81$ & $\mathrm{CC}$ & Sär 1 & $\begin{array}{l}\text { Skandfer 2005, } \\
2009\end{array}$ \\
\hline Tua-3026 & $\begin{array}{l}\text { Sör-Varanger Noatun } \\
\text { Neset Vest }(\mathrm{N})\end{array}$ & $\mathrm{N}$ & $6030 \pm 70$ & -23.0 & $5865 \pm 100$ & $\mathrm{CC}$ & Sär 1 & $\begin{array}{l}\text { Skandfer 2005, } \\
2009\end{array}$ \\
\hline Hela-128 & Oulu Vepsänkangas (F) & $\mathrm{N}$ & $995 \pm 65$ & -22.2 & $5837 \pm 100$ & $\mathrm{CC}$ & Sär 1 & Torvinen 2000 \\
\hline Hela-312 & Oulu Vepsänkangas (F) & $\mathrm{N}$ & $5990 \pm 60$ & -27.3 & & BBT & Sär 1 & Koivisto 1998 \\
\hline Tua-3027 & $\begin{array}{l}\text { Sör-Varanger Mennikka } \\
(\mathrm{N})\end{array}$ & $\mathrm{N}$ & $5975 \pm 60$ & -24.4 & $5887 \pm 84$ & $\mathrm{CC}$ & Sär 1 & $\begin{array}{l}\text { Skandfer 2005, } \\
2009\end{array}$ \\
\hline Beta-13126 & $\begin{array}{l}\text { Sör-Varanger Noatun } \\
\text { Neset }(\mathrm{N})\end{array}$ & $\mathrm{N}$ & $5950 \pm 90$ & & & $\mathrm{CC}$ & Sär 1 & $\begin{array}{l}\text { Skandfer 2005, } \\
2009\end{array}$ \\
\hline Tua-3929 & $\begin{array}{l}\text { Sör-Varanger Noatun In- } \\
\text { nmarken (N) }\end{array}$ & $\mathrm{N}$ & $5850 \pm 55$ & -21.2 & $5585 \pm 106$ & $\mathrm{CC}$ & Sär 1 & $\begin{array}{l}\text { Skandfer 2005, } \\
2009\end{array}$ \\
\hline Hela-38 & Inari Rönkön raivio (F) & $\mathrm{N}$ & $5830 \pm 85$ & -28.2 & & $\mathrm{CC}$ & Sär 1 & Torvinen 2000 \\
\hline Hela-34 & Kemijärvi Neitilä 4 (F) & $\mathrm{N}$ & $5800 \pm 90$ & -25.1 & $5763 \pm 99$ & $\mathrm{CC}$ & Sär 1 & Torvinen 2000 \\
\hline Hela-146 & Oulu Latokangas (F) & $\mathrm{N}$ & $5795 \pm 90$ & -27.0 & & $\mathrm{CC}$ & Sär 1 & Torvinen 2000 \\
\hline Tua-3022 & $\begin{array}{l}\text { Sör-Varanger Mennikka } \\
\text { (N) }\end{array}$ & $\mathrm{N}$ & $5795 \pm 55$ & -22.1 & $5580 \pm 98$ & $\mathrm{CC}$ & Sär 1 & $\begin{array}{l}\text { Skandfer 2005, } \\
2009\end{array}$ \\
\hline Hela-42 & Oulu Latokangas (F) & $\mathrm{N}$ & $5790 \pm 105$ & -25.7 & $5778 \pm 111$ & $\mathrm{CC}$ & Sär 1 & Torvinen 2000 \\
\hline Hela-40 & $\begin{array}{l}\text { Rovaniemi Ylitalo/Toiv- } \\
\text { ola (F) }\end{array}$ & $\mathrm{N}$ & $5520 \pm 185$ & -20.3 & $5283 \pm 212$ & $\mathrm{CC}$ & Sär 1 & Torvinen 2000 \\
\hline Hela-57* & $\begin{array}{l}\text { Rovaniemi Jokkavaara } \\
\text { (F) }\end{array}$ & $\mathrm{N}$ & $5070 \pm 80$ & -25.9 & $5066 \pm 80$ & $\mathrm{CC}$ & Sär 1 & Torvinen 2000 \\
\hline
\end{tabular}

\section{APPENDIX 2: OXCal CODE}

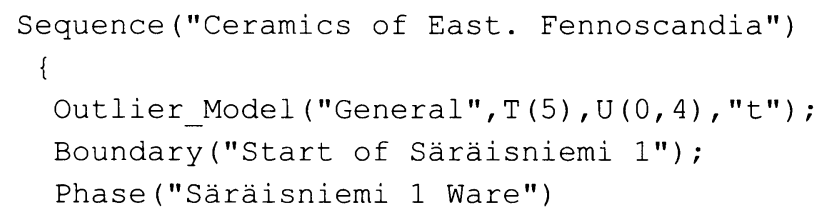




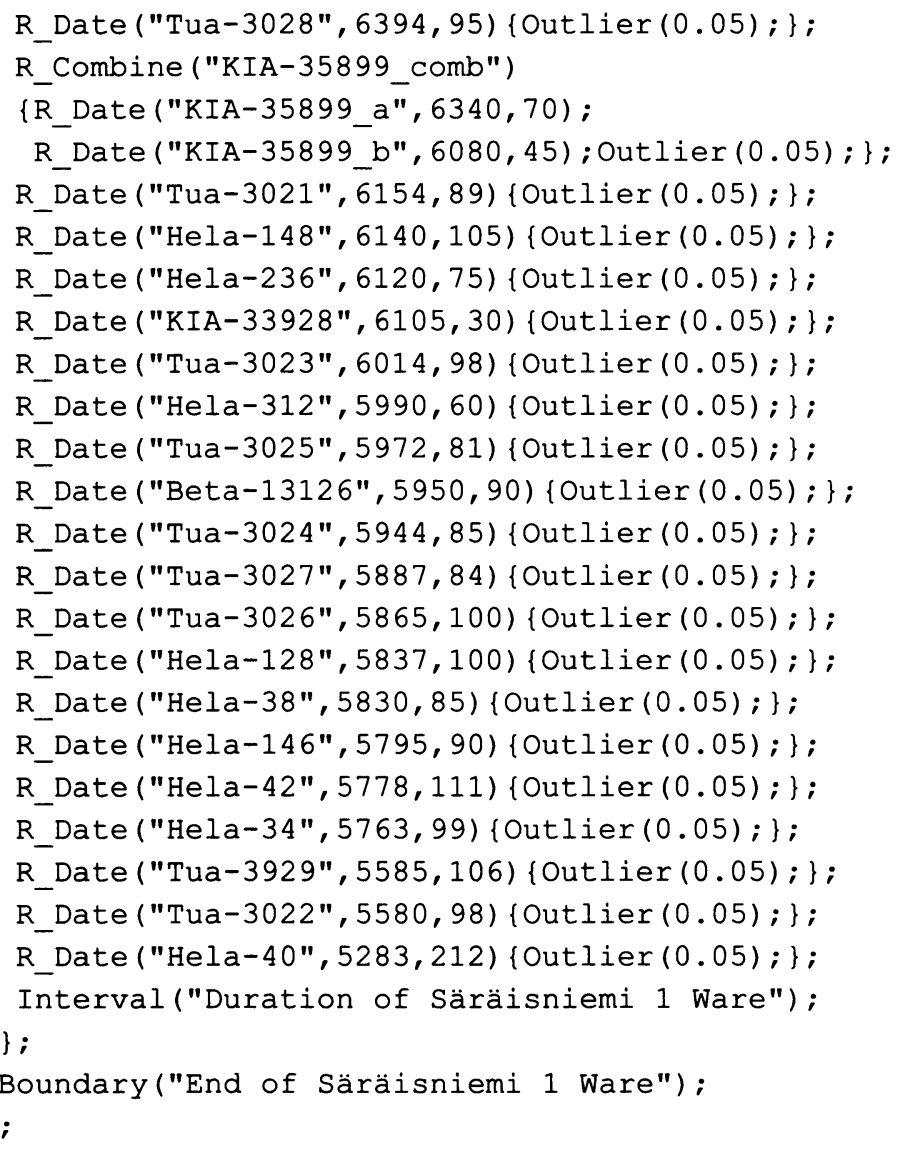

